\title{
Efficacy of Different Insecticides against Green Semilooper Chrysodeixis acuta on Soybean
}

\author{
G.V. Wagh ${ }^{1}$ and K.P. Budhvat ${ }^{2^{*}}$ \\ ${ }^{1}$ College of Agriculture Nagpur, Dr.PDKV, Akola, India \\ ${ }^{2}$ Shri Shivaji Agriculture College, Amravati, India \\ *Corresponding author
}

\section{A B S T R A C T}

\begin{tabular}{l} 
Ke y w o r d s \\
Chemical \\
insecticide, Green \\
semilooper \\
Chrysodeixis acuta \\
and soybean \\
\hline Article Info \\
$\begin{array}{l}\text { Accepted: } \\
\text { 22 July 2020 } \\
\text { Available Online: } \\
\text { 10 August } 2020\end{array}$
\end{tabular}

The present study entitled, efficacy of Different Insecticides against Green Semilooper Chrysodeixis acuta on Soybean was undertaken incorporating nine treatments were evaluated for their efficacy against Green Semilooper on soybean. The experiment was laid out in RBD and was conducted during kharif season of 2013-14. The results were found to be statistically significant. However, numerically minimum cumulative average numbers of larvae of Green Semilooper were recorded treatment (T4) Profenophos 50EC @ $0.185 \%$ followed by the Treatment (T3) Profenophos 50EC @ 0.125\%, (T6) Quinalphos25EC @ 0.075\%, (T5) Quinalphos 25 EC @ 0.05\%, (T2) Chlorpyriphos 20EC @ 0.06\%, (T1) Chlorpyriphos 20 EC @ 0.04\%, (T8) Triazophos 40 EC @ 0.06\% and (T7) Triazophos 40 EC @ 0.04\%. The treatment (T4) Profenophos 50EC @ 0.185\% ranked first in recording maximum yield but, in treatment (T3) Profenophos 50EC @ $0.125 \%$ highest ICBR was recorded. The other treatments in descending order in respect of yield were of $\mathrm{T} 3>\mathrm{T} 6>\mathrm{T} 5>\mathrm{T} 2>\mathrm{T} 1>\mathrm{T} 8>\mathrm{T} 7$ and regarding $\mathrm{ICBR} \mathrm{T} 4>\mathrm{T} 5>\mathrm{T} 6>\mathrm{T} 1>\mathrm{T} 2$ $>\mathrm{T} 7>\mathrm{T} 8$. The overall picture on the basis of ICBR and yield of treatment, the treatment (T3) profenophos 50 EC @ $0.125 \%$ and (T4) profenophos 50 EC @ $0.185 \%$ shown promise in recording lower infestation of soyabean semilooper.

\section{Introduction}

Soybean (Glycine max L.) is one of the miracles 'Golden bean' of the $20^{\text {th }}$ century. In India, soybean was first time introduced as food in 1935 (Sharma, 2004). Soybean possess a very high nutritional value, on an average it contains 20 per cent oil, 40 per cent protein, Vit A, B, C, D, E and $\mathrm{K}$ along with 0.69 per cent phosphorus, 0.112 per cent iron and 0.024 per cent calcium. Edible soya proteins are one of the worlds least expensive and high quality protein source (Bishnoi, 2005). This crop is attacked by 88 insect pest species belonging to six different orders of insects and some mites. Most economic injury caused by 25 insects belongs to order Lepidoptera and Hemiptera. Insect pests associated with crop are (Aphid Aphis gossypii, Aphis craccivora), Whitefly (Bemisia tabaci), Green semilooper (Chrysodeixis acuta), Bihar Hairy caterpillar 
(Spilosoma oblique), Girldle beetle (Obereopsis brevis), Stem fly (Melanagromyza sojae), Tobacco leaf eating caterpillar (Spodoptera litura), Leaf miner (Aproaerema modicella), Grasshopper (Atractomorpha crenulata) and Grey weevil (Mylocerus undecimpustulatus), (Singh and Singh, 1990). Among them, the leaf defoliator's viz., green semilooper (Chrysodeixis acuta) are the noxious pests that damage the soybean crop extensively by skeletonizing the leaves and thus reducing the photosynthetic capacity of the plant. Many insecticides have been involved for the control of these notorious pests (Purwar and Yadav, 2003, Harish, 2008). At present, synthetic insecticides have been used extensively to overcome the pest problem but indiscriminate use, resulted in number of problems viz., the development of insect resistance to insecticides and induced resurgence of secondary pests (Dodia et al, 2008). The Present study entitles efficacy different insecticides against green semilooper on soybean were help in selection of most effective chemical insecticide against green semilooper (Chrysodeixis acuta) of soybean.

\section{Materials and Methods}

The experiment was conducted at Agricultural Entomology Section, College of Agriculture Nagpur during kharif season 2013-2014. Details of materials used for conducting these studies land, soybean seed (JS-335), insecticides, agricultural implements, manures and fertilizers, knapsack sprayer, measuring tape, rope, pegs, tags, bullock pair, labours, polythene bags, weighing balance etc were utilized and the methods followed during the course of studies are described herewith. The trail was laid out in Randomized block design with nine treatments and three replication. The soybean variety JS- 335 was sown on dated 18 June 2013 at $45 \times 0.5 \mathrm{~cm}$ spacing.
The plot size was kept $4.5 \times 3.0 \mathrm{~m}$. The chemical treatments(T1) Chlorpyriphos 20 EC@ 0.04\%, (T2) Chloropyriphos 20EC @ 0.06\%, (T3) Profenophos 50 EC @ 0.125\%, (T4) Profenophos 50 EC @0.185\%, (T5) Quinalphos 25 EC 0.05\%, (T6) Quinalphos 25 EC@0.075\%, (T7) Triazophos 40EC @ 0.04\%, (T8) Triazophos 40 EC @ 0.06\% and (T9) control (water spray) were evaluated.

\section{Methods of recording observation}

The observations on green semilooper was recorded on randomly selected one meter row length at five places from each plot, 24 hours before the application of treatments and the post treatment observations were recorded at 7 and 14 days after application of treatment. The yield of soybean from each net plot was recorded to know the influence of the different treatments. The yield data from each treated plot were used to calculate economics of spraying. The cost of insecticide cost of spray applications i.e. labour charges prevailing during the course of investigations were taken into consideration to work out the cost of each treatment per hectare. Similarly, income obtained from the sale of soybean as per the prevailing market rates was also calculated for each treatment to work out the cost benefit ratio. The field data collected during the course of experimentation was subjected to statistical analysis after appropriate transformation for interpretation of results. Randomized block design used in order to test level of significance among the various treatments as per Gomez and Gomez (1984).

\section{Results and Discussion}

The present study was evaluated for their efficacy against Green semilooper on soybean. The average population of major pests on soybean was observed at 7 and 14 days after each spray application. The average 
population in each treatment was worked out. Then data was transformed into corresponding square root values and was subjected to statistical analysis.

Effect of different treatments on average population of green semilooper larvae 7 and 14 days after first spray

\section{AT 7DAS}

The data on average number of larvae of Semilooper/mrl was recorded at 7 DAS after $1^{\text {st }}$ spray is presented in Table 1 . The treatments (T4) Profenophos 50 EC @ $0.185 \%(0.53 / \mathrm{mrl})$ was found to be most effective treatment but was at par with the treatments of (T3) Profenophos 50 EC @ $0.125 \%$ (0.83/mrl), (T6) Quinalphos 25EC @ $0.075 \%$ (1.13/mrl), (T5) Quinalphos 25 EC @ $0.05 \%(1.03 / \mathrm{mrl})$ and (T2) Chlorpyriphos 20 EC @ 0.06\% (1.07/mrl). The next superior treatments were of (T1) Chlorpyriphos 20 EC @ $0.04 \%(1.33 / \mathrm{mrl})$ which observed to be equally effective with (T8) Triazophos 40 EC @ $0.06 \%(1.63 / \mathrm{mrl})$ followed by the treatment of (T7) Triazophos 40 EC @ $0.04 \%$ $(1.77 / \mathrm{mrl})$.

The maximum average number of larvae of semilooper $(3.10 / \mathrm{mrl})$ was recorded in treatment (T9) control. The above results are on parallel line with the findings of Raju et al., (2013), who reported Profenophos 50 EC @ $1250 \mathrm{ml} / \mathrm{ha}$ and Quinalphos 25 EC @ $1500 \mathrm{ml} / \mathrm{ha}$ to offer maximum protection against green semilooper upto 35 DAG after application of first spray and reported 0.00 larvae/mrl and 0.11 larvae/mrl, respectively. Khandwe and Waghmare (2003) studied the efficacy of chlorpyriphos 20 EC against green semilooper, $C$. acuta on soybean. A single spray of chlorpyriphos $(0.1 \%)$ at 30 days after sowing (DAS) was highly effective in reducing the larval population to 0.33 larvae per 10 plant as compared with 8 larvae per plant in the untreated control.

\section{AT 14 DAS}

The data on average number of larvae of semilooper/mrl recorded at 14 DAS after $1^{\text {st }}$ spray are presented in Table 1 . The result was found significant. The treatment (T4) Profenophos 50 EC @ 0.185\% (0.97/mrl)was observed significantly superior treatment and was at par with (T3) Profenophos 50 EC @ 0.125\% (1.13/mrl), (T6) Quinalphos 25 EC @ 0.075\% (1.27/mrl), (T5) Quinalphos 25 EC @ $0.05 \%(1.43 / \mathrm{mrl})$, (T2) Chlorpyriphos $20 \mathrm{EC}$ @ 0.06\% (1.53/mrl) and (T1) Chlorpyriphos 20 EC @ 0.04\% (1.70/mrl) followed by treatments of ( T8) Triazophos 40 EC @ $0.06 \%(1.83 / \mathrm{mrl})$ and ( T7) Triazophos $40 \mathrm{EC}$ @ $0.04 \%(2.03 / \mathrm{mrl})$ which proved equally effective amongst each other. Maximum average number of larvae of semilooper $(4.17 / \mathrm{mrl})$ was recorded in (T9) control (water spray). Balaji et al., (2012) reported diafenthiuron $50 \mathrm{WP}$, profenofos $50 \mathrm{EC}$, triazophos $40 \mathrm{EC}$ and emamectin benzoate 5 $\mathrm{SG}$ to be highly effective against green semilooper and remained effective upto 5 days after treatment. Singh and Singh (1987) studied the incidence and damage caused by the noctuid Chrysodeixis acuta to soyabean pods and flowers and reported effective control by the treatment with quinalphos $25 \mathrm{EC}$ at $0.05 \%$ upto 42 days after spraying.

\section{Effect of different treatments on average population of green semilooper larvae 7 and 14 days after second spray}

\section{AT 7 DAS}

The data on average number of larvae of semilooper/mrl were recorded at 7 DAS after $2^{\text {nd }}$ spray are presented in Table 1 . The treatment (T4) Profenophos 50 EC @ 0.185\% found $(0.70 / \mathrm{mrl})$ significantly superior all over other treatments but was at par with the treatments of ( T3) Profenophos 50 EC @ 0.125\% (0.87/mrl), ( T6) Quinalphos 25 EC@ 
$0.075 \%(0.93 / \mathrm{mrl})$ followed by treatments (T5) Quinalphos 25 EC @ 0.05\% (1.07/mrl), (T2) Chlorpyriphos 20 EC @ $0.06 \%$ (1.20/mrl) and (T1) Chlorpyriphos 20 EC @ $0.04 \% \quad(1.27 / \mathrm{mrl})$. The next superior treatments were of (T8) Triazophos 40 EC @ $0.06 \%(1.77 / \mathrm{mrl})$ and (T7) Triazophos $40 \mathrm{EC}$ @ 0.04\% (1.90/mrl). Maximum average number of larvae of Spodoptera $(4.73 / \mathrm{mrl})$ was recorded in (T9) control (water spray).

The above results are in confirmation with the findings of Raju et al., (2013) who reported Pofenophos 50 EC @ $1250 \mathrm{ml} / \mathrm{ha}$ and Quinalphos 25 EC @ 1500ml/ha to be effective against green semilooper upto 55 DAG after application of first spray and reported 0.77 larvae $/ \mathrm{mrl}$ and 0.61 larvae $/ \mathrm{mrl}$, respectively. Balaji et al., (2012) reported diafenthiuron $50 \mathrm{WP}$, profenophos $50 \mathrm{EC}$, triazophos $40 \mathrm{EC}$ and emamectin benzoate 5 $\mathrm{SG}$ to be highly effective against green semilooper and remained effective upto 5 days after treatment. Dubey et al., (1998) reported triazophos $40 \mathrm{EC}$ as highly and significantly more toxic against Green semilooper (Chrysodeixes accuta).

\section{AT 14 DAS}

The data on average number of larvae of semilooper/mrl were recorded after $2^{\text {nd }}$ spray at 14 DAS is presented in Table 1. The treatment (T4) Profenophos 50 EC @ 0.185\% $(0.80 / \mathrm{mrl})$ was found significantly superior over all other treatments but was also found at par with the treatments of (T3) Profenophos 50EC @ 0.125\% (1.00/mrl), (T6) Quinalphos 25 EC @ $0.075 \% \quad(1.40 / \mathrm{mrl})$ and (T5) Quinalphos 25 EC @ 0.05\% (1.60/mrl). The next effective treatments were of (T2) Chlorpyriphos 20 EC @ $0.06 \%$ (1.80/mrl) which was at par with the treatments of (T1) Chlorpyriphos 20 EC @ 0.04\% (1.93/mrl), (T8) Triazophos 40 EC @ 0.06\% (1.97/mrl) and (T7) Triazophos 40 EC @ $0.04 \%$ (2.20/mrl). Maximum average larval population $(5.03 / \mathrm{mrl})$ was recorded in (T9) control plots. Similar results were reported by Singh and Singh (1987) who studied the incidence and damage caused by the noctuide Chrysodeixis acuta to soyabean pods and flowers and reported effective control by the treatment with quinalphos at $0.05 \%, 42$ days after spraying. Nagrale et al., (2009) reported treatment of Quinalphos 25 EC $0.05 \%$ as most significantly superior over all the other treatments and recorded maximum green semilooper (83.80, 66.64, 72.26, 63.93, 97.42, 97.00) per cent larval reduction and was at par with Neem seed extract $5 \%$ to some extent in which 60.90 per cent larval reduction was observed after three spraying.

Effect of different treatments on average population of green semilooper larvae 7 and 14 days after third spray

\section{AT 7DAS}

The data on average number of larvae of semilooper $/ \mathrm{mrl}$ were recorded at 7 DAS after $3^{\text {rd }}$ spray are presented in Table 1 . All the treatments were found significantly superior over the control. The treatment (T4) Profenophos 50 EC @ 0.185\% (0.00/mrl)) was the most superior treatment which was at par with (T3) Profenophos 50 EC @ 0.125\% (0.00/mrl), (T6) Quinalphos 25 EC @ 0.075\% (0.07/mrl), (T5) Quinalphos 25 EC @ 0.05\% (0.17/mrl), (T2) Chlorpyriphos 20 EC @ $0.06 \%(0.23 / \mathrm{mrl})$ and (T1) Chlorpyriphos 20 EC @ 0.04\% (0.37/mrl).

The next superior treatment recorded (T8) Triazophos $40 \quad$ EC $@ 0.06 \% \quad(0.53 / \mathrm{mrl})$ followed by treatment (T7) Triazophos $40 \mathrm{EC}$ @ 0.04\% (0.83/mrl). The maximum average number of larvae of semilooper $(4.50 / \mathrm{mrl})$ was recorded in (T9) control (water spray).Balaji et al.(2012) reported diafenthiuron $50 \mathrm{WP}$, profenophos $50 \mathrm{EC}$, triazophos $40 \mathrm{EC}$ and emamectin benzoate 5 $\mathrm{SG}$ to be highly effective against 
green semilooper and remained effective upto 5 days after treatment. Khandwe and Waghmare (2003) studied the efficacy of chlorpyriphos 20 EC sprays against green semiloopers, C. acuta on soyabean. A single spray of chlorpyriphos $(0.1 \%)$ at 30 days after sowing (DAS) was highly effective in reducing the larval population to 0.33 larvae per 10 plants as compared with 8 larvae per plant in the untreated control. So, the present results could be compared with the findings of those workers.

\section{AT 14 DAS}

The data on average number of larvae of semilooper/mrl recorded at 14 DAS after $3^{\text {rd }}$ spray are presented in Table 1 . The result was found most significant in treatment (T4) Profenophos 50 EC @ 0.185\% (0.00/mrl). But this treatment was found at par with treatments (T3) Profenophos 50 EC @ 0.125\% (0.17/mrl), (T6) Quinalphos 25 EC @ $0.075 \% \quad(0.27 / \mathrm{mrl})$. The next superior treatments recorded were of (T5) Quinalphos 25 EC @ 0.05\% (0.50/mrl) which was at par with treatments (T2) Chlorpyriphos 20 EC @ 0.06\% (0.73/mrl), (T1) Chlorpyriphos 20 EC @ $0.04 \% \quad(0.97 / \mathrm{mrl})$ followed by (T8) Triazophos 40 EC @ $0.06 \%(1.10 / \mathrm{mrl})$ and (T7) Triazophos 40 EC @ 0.04\% (1.23/mrl). Maximum average number of larvae of semilooper $(4.13 / \mathrm{mrl})$ was recorded in treatment (T9), control plots.

Dubey et al., (1998) reported Triazophos 40 EC as highly and significantly more toxic against green semilooper (Chrysodeixes accuta). Nagrale et al.(2009) reported Quinalphos 25 EC $0.05 \%$ as significantly superior over all the other treatments and recorded maximum green semilooper $(83.80$, $66.64,72.26,63.93,97.42,97.00)$ per cent larval reduction and was at par with Neem seed extract $5 \%$ to some extent in which 60.90 per cent larval reduction was observed after three spraying.
Cumulative mean population of Green semilooper larvae in different treatments at 7 DAS and 14 DAS after three spraying AT 7 DAS

The data on cumulative mean number of larvae of semilooper/mrl recorded at 7 DAS and presented in Table 1 . The result was found to be statistically significant. However, numerically minimum number of larvae of semilooper $(0.41 / \mathrm{mrl})$ was recorded in treatment (T4) Profenophos 50 EC @ 0.185\% which was at par with treatments (T3) Profenophos 50 EC @ 0.125\% (0.57/mrl), (T6) Quinalphos 25 EC @ 0.075\% (0.71/mrl), (T5) Quinalphos 25 EC @ 0.05\% (0.76/mrl) and (T2) Chlorpyriphos 20 EC @ $0.06 \%(0.83 / \mathrm{mrl})$. The next effective treatments were of (T1) Chlorpyriphos $20 \mathrm{EC}$ @ 0.04\% (0.99/mrl), (T8) Triazophos 40 EC @ 0.06\%(1.31/mrl) and (T7) Triazophos 40 EC@0.04\% (1.50/mrl). While, maximum cumulative average number of semilooper larvae $(4.11 / \mathrm{mrl})$ was recorded in (T9) control (water spray). The above results are in confirmation with Balaji et al., (2012) who reported diafenthiuron $50 \mathrm{WP}$, profenophos 50 EC, triazophos $40 \mathrm{EC}$ and Emamectin benzoate $5 \mathrm{SG}$ to be highly effective against green semilooper and remained effective upto 5 days after treatment. Khandwe and Waghmare (2003) studied the efficacy of chlorpyriphos 20 EC sprays against green semiloopers, C. acuta on soybean. A single spray of chlorpyriphos $(0.1 \%)$ at 30 days after sowing (DAS) was highly effective in reducing the larval population to 0.33 larvae per 10 plants as compared with 8 larvae per plant in the untreated control.

\section{AT 14 DAS}

The data on cumulative mean number of larvae of semilooper/mrl recorded at 14 DAS and presented in Table 1 . The result was found to be statistically significant. However, minimum cumulative average number of 
semilooper larvae $(0.59 / \mathrm{mrl})$ was recorded in treatment (T4) Profenophos 50EC @ 0.185\% which was also found at par with the treatments (T3) Profenophos 50 EC @ 0.125\% (0.77/mrl), (T6) Quinalphos 25 EC @ 0.075\% (0.98/mrl), (T5) Quinalphos 25 EC @ $0.05 \%(1.18 / \mathrm{mrl})$ and (T2) Chlorpyriphos 20 EC@ $0.06 \%(1.35 / \mathrm{mrl})$. The next effective treatments were of (T1) Chlorpyriphos $20 \mathrm{EC}$ @ 0.04\% (1.53/mrl), (T8) Triazophos 40EC @ $0.06 \%(1.63 / \mathrm{mrl})$ and (T7) Triazophos 40EC @ 0.04\% (1.82/mrl). While, maximum cumulative average number of larvae of semilooper $(4.44 / \mathrm{mrl})$ was recorded in (T9) control (water spray). The above results are in confirmation with the findings of Raju et al., (2013) who reported Profenophos 50 EC @ $1250 \mathrm{ml} / \mathrm{ha}$ and Quinalphos 25 EC @ $1500 \mathrm{ml} / \mathrm{ha}$ to offer maximum protection against green semilooper which was recorded upto $35 \mathrm{DAG}$ after application of first spray and reported 0.00 larvae/mrl and 0.11 larvae/mrl, respectively. Dubey et al., (1998) reported that Triazophos 40 EC was highly and significantly more toxic against green semilooper (Chrysodeixes accuta).

\section{Effect of different treatments on Average yield of Soybean crop}

The plots treated with Profenophos 50 EC @ $0.185 \%$ recorded maximum yield of soybean i.e. $22.75 \mathrm{q} /$ ha followed by (T3) Profenophos 50 EC @ 0.125\% and (T6) Quinalphos25 EC @ 0.075\% recording 20.29 q/ha and 19.23 $\mathrm{q} /$ ha yield and were found to be statistically at par with each other and significantly superior over rest of the treatments. However, the yield recorded in the treatments of (T3) Profenophos 50 EC @ 0.125\% (20.29 q/ha) followed by, (T6) Quinalphos25 EC @ 0.075 $\%$ (19.23q/ha), (T5) Quinalphos 25 EC @ $0.05 \%$ (18.48q/ha), (T2) Chlorpyriphos20 EC @ 0.06\% (16.34q/ha), (T1) Chlorpyriphos 20 EC @ 0.04\% (15.70q/ha), (T8) Triazophos 40 EC @ $0.06 \%$ (15.06q/ha) and (T7)
Triazophos 40 EC @ 0.04(14.63q/ha) and were found statistically at par with each other but found significantly superior over control (T9; water spray) in which 9.40 q/ha yield was recorded. The above results are in confirmation with Keshbhat et al., (2002) who recorded the efficacy of Quinalphos $0.05 \%$, Decamethrin $0.0025 \%$ and Profenophos $0.15 \%$ in reducing larval population. It was also reported that, maximum grain yield was recorded in Profenophos (31.24 q/ha) followed by Quinalphos (29.62 q/ha) and Decamethrin (29.39 q/ha) and were at par with each other. These observations are comparable with the yield observation reported by Sinha et al., (2013) who reported Profenophos 50 EC @ $0.1 \%$ as most effective against lepodepterian pests with $19.40 \mathrm{q} /$ ha yield with the increase in the yield up to $8.15 \mathrm{q} /$ ha over control.

\section{Incremental cost benefit ratio (ICBR) for different treatments}

The data presented in Table 2 with parameters increased yield over control ( $\mathrm{q} / \mathrm{ha}$ ) revealed that, the treatment with three spraying of profenophos 50 EC @ $0.125 \%$ (T3) had offered the maximum ICBR to the extent of 6.43 followed by (T4) profenophos 50 EC @ $0.185 \%$ (6.41); (T5) Quinalphos 25 EC @ $0.05 \%$ (6.24); (T6) Quinalphos 25 EC @ $0.075 \%$ (5.55); (T1) Chlorpyriphos 20 EC @ 0.04\% (5.25); (T2) Chlorpyriphos 20 EC @ 0.06\% (5.14); (T7) Triazophos 40 EC @ 0.04\% (3.90); (T8) Triazophos 40 EC @ $0.06 \%$ (3.64).

The above results are in confirmation with Raju et al., (2013) who reported that, spraying of triazophos was economical and most remunerative and recorded 1: 7.32 ICBR, followed by profenophos 50 EC @ 1250 $\mathrm{ml} / \mathrm{ha}(1: 5.36)$ and quinalphos 25 EC @ 1500 $\mathrm{ml} / \mathrm{ha}(1: 5.09)$. 
From the findings of the present investigations, it could be concluded that, minimum average population of Green semilooper was observed in the treatments of (T4) Profenophos50 EC @ 0.185\%followed by treatment (T3) Profenophos50EC @ 0.125\%, (T6) Quinalphos 25 EC @ 0.075\%, (T5) Quinalphos 25 EC @ 0.05\%, (T2) Chlorpyriphos 20 EC @ 0.06\%, (T1) Chlorpyriphos 20 EC @ 0.04\%, (T8) Triazophos 40 EC @ $0.06 \%$ and (T7) Triazophos 40 EC @ 0.04\% 7 and 14 days after three sprayings and were proved to be effective in controlling the semilooper. The treatment (T4) Profenophos 50EC @ 0.185\% ranked first in recording maximum yield but in treatment (T3) Profenophos50EC @ $0.125 \%$ highest ICBR was recorded. The other treatments in descending order in respect of yield were of $\mathrm{T} 3>\mathrm{T} 6>\mathrm{T} 5>\mathrm{T} 2>$ $\mathrm{T} 1>\mathrm{T} 8>\mathrm{T} 7$ and regarding $\mathrm{ICBR} \mathrm{T} 4>\mathrm{T} 5>$ $\mathrm{T} 6>\mathrm{T} 1>\mathrm{T} 2>\mathrm{T} 7>\mathrm{T} 8$. The overall picture on the basis of ICBR and yield of treatment, the treatment (T3) profenophos 50 EC @ $0.125 \%$ and(T4) profenophos 50 EC @ $0.185 \%$ shown promise in recording lower infestation of soyabean defoliators and comparative higher yield but further needs to be tested.

Table.1 Cumulative mean population of green semilooper larvae in different treatments at 7 and 14 days after three spraying

\begin{tabular}{|c|c|c|c|c|c|c|c|c|c|}
\hline \multirow{2}{*}{$\begin{array}{c}\text { Tr. } \\
\text { No. }\end{array}$} & \multirow[t]{2}{*}{ Treatments } & \multicolumn{4}{|c|}{7 DAS } & \multicolumn{4}{|c|}{14 DAS } \\
\hline & & $\begin{array}{c}1 \text { st } \\
\text { spray }\end{array}$ & $\begin{array}{l}2 \text { nd } \\
\text { spray }\end{array}$ & $\begin{array}{c}3 \text { rd } \\
\text { spray }\end{array}$ & Mean & $\begin{array}{c}1 \text { st } \\
\text { spray }\end{array}$ & $\begin{array}{l}2 \text { nd } \\
\text { Spray }\end{array}$ & $\begin{array}{c}3 \text { rd } \\
\text { spray }\end{array}$ & Mean \\
\hline T1 & Chlorpyriphos 20 EC @0.04\% & $\begin{array}{c}1.33 \\
(1.35)\end{array}$ & $\begin{array}{c}1.27 \\
(1.32)\end{array}$ & $\begin{array}{c}0.37 \\
(0.93)\end{array}$ & $\begin{array}{c}0.99 \\
(1.21\end{array}$ & $\begin{array}{c}1.70 \\
(1.47)\end{array}$ & $\begin{array}{c}1.93 \\
(1.55)\end{array}$ & $\begin{array}{c}0.97 \\
(1.20)\end{array}$ & $\begin{array}{c}1.53 \\
(1.42)\end{array}$ \\
\hline $\mathbf{T 2}$ & Chlorpyriphos 20 EC @0.06\% & $\begin{array}{c}1.07 \\
(1.25)\end{array}$ & $\begin{array}{c}1.20 \\
(1.30)\end{array}$ & $\begin{array}{c}0.23 \\
(0.86)\end{array}$ & $\begin{array}{c}0.83 \\
(1.14)\end{array}$ & $\begin{array}{l}1.53 \\
1.42)\end{array}$ & $\begin{array}{c}1.80 \\
(1.51)\end{array}$ & $\begin{array}{c}0.73 \\
(1.08)\end{array}$ & $\begin{array}{c}1.35 \\
(1.35)\end{array}$ \\
\hline T3 & Profenophos 50 EC @0.125\% & $\begin{array}{c}0.83 \\
(1.15)\end{array}$ & $\begin{array}{c}0.87 \\
(1.16)\end{array}$ & $\begin{array}{c}0.00 \\
(0.71)\end{array}$ & $\begin{array}{l}0.57 \\
(1.01)\end{array}$ & $\begin{array}{c}1.13 \\
(1.27)\end{array}$ & $\begin{array}{c}1.00 \\
(1.22)\end{array}$ & $\begin{array}{c}0.17 \\
(0.82)\end{array}$ & $\begin{array}{c}0.77 \\
(1.11)\end{array}$ \\
\hline T4 & Profenophos 50 EC @0.185\% & $\begin{array}{c}0.53 \\
(1.01)\end{array}$ & $\begin{array}{c}0.70 \\
(1.09)\end{array}$ & $\begin{array}{c}0.00 \\
(0.71)\end{array}$ & $\begin{array}{c}0.41 \\
(0.94\end{array}$ & $\begin{array}{c}0.97 \\
(1.20)\end{array}$ & $\begin{array}{c}0.80 \\
(1.14)\end{array}$ & $\begin{array}{c}0.00 \\
(0.71)\end{array}$ & $\begin{array}{c}0.59 \\
(1.02)\end{array}$ \\
\hline T5 & Quinalphos 25 EC @0.05\% & $\begin{array}{c}1.03 \\
(1.23)\end{array}$ & $\begin{array}{c}1.07 \\
(1.25)\end{array}$ & $\begin{array}{c}0.17 \\
(0.82)\end{array}$ & $\begin{array}{c}0.76 \\
(1.10)\end{array}$ & $\begin{array}{c}1.43 \\
(1.39)\end{array}$ & $\begin{array}{c}1.60 \\
(1.44)\end{array}$ & $\begin{array}{c}0.50 \\
(1.00)\end{array}$ & $\begin{array}{c}1.18 \\
(1.28)\end{array}$ \\
\hline T6 & Quinalphos 25 EC@ 0.075\% & $\begin{array}{c}1.13 \\
(1.27)\end{array}$ & $\begin{array}{c}0.93 \\
(1.19)\end{array}$ & $\begin{array}{c}0.07 \\
(0.75)\end{array}$ & $\begin{array}{c}0.71 \\
(1.08)\end{array}$ & $\begin{array}{c}1.27 \\
(1.32)\end{array}$ & $\begin{array}{c}1.40 \\
(1.37)\end{array}$ & $\begin{array}{c}0.27 \\
(0.87)\end{array}$ & $\begin{array}{c}0.98 \\
(1.20)\end{array}$ \\
\hline T7 & Triazophos40 EC @0.04\% & $\begin{array}{c}1.77 \\
(1.51)\end{array}$ & $\begin{array}{c}1.90 \\
(1.55)\end{array}$ & $\begin{array}{c}0.83 \\
(1.14)\end{array}$ & $\begin{array}{c}1.50 \\
(1.40)\end{array}$ & $\begin{array}{c}2.03 \\
(1.57)\end{array}$ & $\begin{array}{c}2.20 \\
(1.64)\end{array}$ & $\begin{array}{c}1.23 \\
(1.31)\end{array}$ & $\begin{array}{c}1.82 \\
(1.52)\end{array}$ \\
\hline T8 & Triazophos 40EC @ 0.06\% & $\begin{array}{c}1.63 \\
(1.46)\end{array}$ & $\begin{array}{c}1.77 \\
(1.50)\end{array}$ & $\begin{array}{c}0.53 \\
(1.01)\end{array}$ & $\begin{array}{c}1.31 \\
(1.33)\end{array}$ & $\begin{array}{c}1.83 \\
(1.52)\end{array}$ & $\begin{array}{c}1.97 \\
(1.57)\end{array}$ & $\begin{array}{c}1.10 \\
(1.26)\end{array}$ & $\begin{array}{c}1.63 \\
(1.45)\end{array}$ \\
\hline T9 & Control (waterspray). & $\begin{array}{c}3.10 \\
(1.88)\end{array}$ & $\begin{array}{c}4.73 \\
(2.28)\end{array}$ & $\begin{array}{c}4.50 \\
(2.22)\end{array}$ & $\begin{array}{c}4.11 \\
(2.14)\end{array}$ & $\begin{array}{c}4.17 \\
(2.12)\end{array}$ & $\begin{array}{c}5.03 \\
(2.33)\end{array}$ & $\begin{array}{c}4.13 \\
(2.14)\end{array}$ & $\begin{array}{c}4.44 \\
(2.20)\end{array}$ \\
\hline & F TEST & Sig. & Sig. & Sig. & Sig & Sig. & Sig. & Sig. & Sig \\
\hline & $\mathrm{SE}(\mathrm{m})$ & 0.09 & 0.09 & 0.07 & 0.07 & 0.09 & 0.11 & 0.08 & 0.11 \\
\hline & CD@5\% & 0.28 & 0.28 & 0.21 & 0.22 & 0.29 & 0.33 & 0.24 & 0.33 \\
\hline & C.V. & 12.29 & 11.80 & 12.93 & 10.32 & 11.35 & 12.47 & 12.24 & 13.94 \\
\hline
\end{tabular}

Figures in parentheses indicates square root transformation $(\sqrt{ } X+0.5)$ 
Table.2 Incremental cost benefit ratio (ICBR) for different treatment

\begin{tabular}{|c|c|c|c|c|c|c|c|c|c|c|c|}
\hline \multirow[t]{2}{*}{ Treatments } & \multirow[b]{2}{*}{$\begin{array}{l}\text { Quantity of } \\
\text { insecticides } \\
\text { required } \\
\text { per ha. } \\
\text { (Lit) }\end{array}$} & \multirow{2}{*}{$\begin{array}{c}\text { Price of } \\
\text { insectici } \\
\text { des } \\
(\mathrm{RS}) / \mathrm{L}\end{array}$} & \multicolumn{2}{|c|}{ Cost of treatment } & \multirow{2}{*}{$\begin{array}{l}\text { Total } \\
\text { cost } \\
\text { Rs/ha } \\
\text { (A) }\end{array}$} & \multirow{2}{*}{$\begin{array}{l}\text { Yield of } \\
\text { soybean } \\
\text { (q/ha) }\end{array}$} & \multirow[b]{2}{*}{$\begin{array}{l}\text { Increase } \\
\text { d yield } \\
\text { over } \\
\text { control } \\
\text { (q/ha) }\end{array}$} & \multirow[b]{2}{*}{$\begin{array}{l}\text { Increas } \\
\text { ed yield } \\
\text { over } \\
\text { control } \\
\text { (Rs/ha) } \\
\text { (B) }\end{array}$} & \multirow[b]{2}{*}{$\begin{array}{c}\text { Net } \\
\text { grain } \\
\text { over } \\
\text { control } \\
\text { (C) } \\
\text { (B-A) }\end{array}$} & \multirow{2}{*}{$\begin{array}{l}\text { ICBR } \\
(\mathbf{C} / \mathrm{A})\end{array}$} & \multirow[t]{2}{*}{ Rank } \\
\hline & & & $\begin{array}{c}\text { Cost of } \\
\text { insecticides } \\
\text { 3sprays } \\
\text { Rs./ha }\end{array}$ & $\begin{array}{l}\text { Labour } \\
\text { charges } \\
\text { and rent } \\
\text { of sprayer } \\
\text { (3 spray) }\end{array}$ & & & & & & & \\
\hline $\begin{array}{l}\text { T1-Choloropyriphos } 20 \text { EC @ } \\
0.04 \%\end{array}$ & 1.00 & 210 & 630 & 1950 & 2580 & 15.70 & 6.30 & 16128 & 13548 & 5.25 & $\mathbf{V}$ \\
\hline $\begin{array}{l}\text { T T2-Choloropyriphos } 20 \text { EC @ } \\
0.06 \%\end{array}$ & 1.50 & 210 & 945 & 1950 & 2895 & 16.34 & 6.94 & 17766 & 14871 & 5.14 & VI \\
\hline T3-Profenophos 50 EC @ $0.125 \%$ & 1.25 & 480 & 1800 & 1950 & 3750 & 20.29 & 10.89 & 27878 & 24128 & 6.43 & I \\
\hline T4 profenophos 50 EC @ $0.185 \%$ & 1.85 & 480 & 2664 & 1950 & 4614 & 22.75 & 13.35 & 34176 & 29562 & 6.41 & II \\
\hline T5 Quinalphos 25 EC @ $0.05 \%$ & 1.00 & 420 & 1260 & 1950 & 3210 & 18.48 & 9.08 & 23245 & 20035 & 6.24 & III \\
\hline T6 Quinalphos 25 EC @ $0.075 \%$ & 1.25 & 420 & 1890 & 1950 & 3840 & 19.23 & 9.83 & 25165 & 21325 & 5.55 & IV \\
\hline T7. Triazophos 40 EC @ .04\% & 0.50 & 520 & 780 & 1950 & 2730 & 14.63 & 5.23 & 13389 & 10659 & 3.90 & VII \\
\hline T8 Triazophos 40 EC @ 0.06\% & 0.75 & 520 & 1170 & 1950 & 3120 & 15.06 & 5.66 & 14890 & 11370 & 3.64 & VIII \\
\hline T9 Control & - & - & - & - & & 9.40 & - & - & - & - & IX \\
\hline
\end{tabular}

1). 5 Labour charges for one spray/ha. @ Rs. 120 / labour / day, 2).charges for hiring 3 Spray pump/ha @ Rs. 25/day/pump,

3). Sale price of Soybean @ Rs. 2560/qtl. $\quad$ 4) Considering 500 lit of water required for one application /ha area of the crop) 


\section{References}

Anonymous, 2012. plant protection schedule, Department of agriculture, state Govt. of Maharashtra.

Balaji, V. M., S. Narayan and V. M. Prasad, 2012. Bio-efficacy of new insecticides against Lepidoptera defoliators and stem borer of soybean. Environment and ecology, 30 (3); 713-716.

Bishnoi, V. 2005. Soybean: As Food Sopa Digest. 2(3):10-12.

Dodia, D.A., I.S. Patel and G.M. Patel, 2008. Botanical Pesticides for Pest Management, pp.1-5.

Dubey, M.P., K.J. Singh, O.P. Singh, S. Chaturvedi, 1998. Bioefficacy and economics of microbial plant agents in field against major insect pest of soybean in M.P. Crop Res 15(253) 256259.

Gangrade, G.A. 1974. Insects of soybean. Tech. Bull. 24: JNKV, Jabalpur, pp. 3233.

Gomez, K.A. and A. A. Gomez,1984. Statistical procedure for agriculture research. New York. John wiley and sons, pp: 20-25.

Gupta, M.P. 2008. Efficacy of economics of biorational and their admixture against incidence of major insect pest of soybean. Ann. pl. Protec. Sci.16(2):282288.

Harish, G. 2008. Studies on incidence and management of defoliator pests of soybean. Msc. Thesis submitted to University of Agriculture science, Dharwad.

Harish, G., R.H. Patil and R.S. Giraddi, 2007. Evaluation of biorational pesticides against lepidopteran defoliators in soybean. Karnataka J. Agric. Sci., 22 (4): (914-917) 2009.

Keshbhat, S. S, V. V Yadav., R. K. Patil, A. S. Kadam and R.P. Kadam, 2002. Efficacy of different insecticides for the control of soybean leaf minor. D.J. Soil and Crop. 12(1)59-61.

Khandwe, N. and S. K. Waghmare, 2003. Chemical control of green semiloopers, Chrysodeixis acuta and Plusia orichalsia in soybean. JNKVV Res. Jr. 37 (2): 108-111.

Kumar, A., M. M. Kumawat and N.K. Meena, 2006. Field evaluation of triazophos against insect pest of soybean and its impact on yield. Pestology vol. 30(8) 14-15.

Nagrale, S.V., V. Tambe and M.J. Deshmukh, 2009. Efficacy of botanicals against defoliators on Soybean. PKV. Research Journals vol. 34 57-60.

Purwar, J. P. and S. R. Yadav, 2003. Field efficacy of pest controlling agents from different origins against tobacco caterpillar, Spodoptera litura on soyabean. Indian J. Ent, 65 (3): 382385.

Raju, G. S., Khandwe, N. and S. Sharma, 2013. Efficacy of insecticides against defoliators and stem borers of Soybean. Ann. Pl. Protec. Sci. 21 (2): 250-253.

Sharma, R. 2004. Soymilk and tofa on update in Indian Context, Sopa Digest, 1:10-13.

Singh, K.J. and O.P. Singh, 1994. persistent toxicity of some synthetic pyrethroid and organophosphate insecticides to grey semilooper and thrips on soybean J. Insect Sci. 7(2): 224-225

Singh, O. P. and K. J. Singh, 1987. Green semilooper, Chrysodeixis acuta, as a pest of flowers and pods and its effect on the grain yield of soybean in Madhya Pradesh. Journal Indian Journal of Agricultural Sciences Vol. 57 No. 11 pp. 861-863.

Singh, O.P. and K.J. Singh, 1988. Effectiveness of some insecticides against the larval population of grey semilooper Riveula sp. a new pest of soybean in Madhya Pradesh. Pesticide. 22(6):29-31. 
Singh, O.P. and K.J. Singh, 1990. Insect pests of soybean and their management. Indian Farming. 39(10):9-14.

Singh, O.P. and K.J. Singh, 1991. Economical threshold level for green semilooper Chrysodeixis acuta (Walk.) on soybean. Tropical Pest Management. 37(4):399402

Sinha, Dinesh and Sahoo, Arun Kumar Sonkar, 2013 Bio-efficacy of
Insecticides against Caterpillar Pests of Soybean Crop. Karan Research Journal of Agricultural Science. Vol. 4, p609$611.3 \mathrm{p}$.

Yadav, M. K., S. M. Matkar, A. N. Sharma, M. Billore, K. N. Kapoor and G. L. Patidar, 2001. Efficacy and economics of some new insecticides against defoliators and stem borers of soybean. Crop research, 21 (1): 88-92.

\section{How to cite this article:}

Wagh, G.V. and Budhvat, K.P. 2020. Efficacy of Different Insecticides against Green Semilooper Chrysodeixis acuta on Soybean. Int.J.Curr.Microbiol.App.Sci. 9(08): 2842-2851. doi: https://doi.org/10.20546/ijcmas.2020.908.319 